\title{
Author Correction: Dynamic ubiquitylation of Sox2 regulates proteostasis and governs neural progenitor cell differentiation
}

\author{
Chun-Ping Cui ${ }^{1}$, Yuan Zhang ${ }^{1}$, Chanjuan Wang ${ }^{1}$, Fang Yuan ${ }^{2,3}$, Hongchang Li ${ }^{1}$, Yuying Yao ${ }^{1}$, Yuhan Chen , \\ Chunnan $\mathrm{Li}^{1}$, Wenyi Wei ${ }^{4}$, Cui Hua Liu (1) ${ }^{5}$, Fuchu He${ }^{1}$, Yan Liu (D) ${ }^{2,3}$ \& Lingqiang Zhang ${ }^{1}$
}

Correction to: Nature Communications; https://doi.org/10.1038/s41467-018-07025-Z; published online 7 November 2018

The original version of this Article contained an error in Fig. 7. In panel c, the lanes of the western blots were incorrectly labelled ' $+/+$ $+/+-I--I-+I++/+-/--I-'$. This has been corrected in both the PDF and HTML versions of the Article.

Published online: 08 January 2019

\begin{abstract}
(c) (i) Open Access This article is licensed under a Creative Commons Attribution 4.0 International License, which permits use, sharing, adaptation, distribution and reproduction in any medium or format, as long as you give appropriate credit to the original author(s) and the source, provide a link to the Creative Commons license, and indicate if changes were made. The images or other third party material in this article are included in the article's Creative Commons license, unless indicated otherwise in a credit line to the material. If material is not included in the article's Creative Commons license and your intended use is not permitted by statutory regulation or exceeds the permitted use, you will need to obtain permission directly from the copyright holder. To view a copy of this license, visit http://creativecommons.org/licenses/by/4.0/.
\end{abstract}

(c) The Author(s) 2019

\footnotetext{
${ }^{1}$ State Key Laboratory of Proteomics, National Center of Protein Sciences (Beijing), Beijing Institute of Lifeomics, 100850 Beijing, China. ${ }^{2}$ State Key Laboratory of Reproductive Medicine, Institute for Stem Cell and Neural Regeneration, School of Pharmacy, Nanjing Medical University, Nanjing, China. ${ }^{3}$ Institute for Stem Cell and Regeneration, Chinese Academy of Science, 100101 Beijing, China. ${ }^{4}$ Department of Pathology, Beth Israel Deaconess Medical Center, Harvard Medical School, Boston, USA. ${ }^{5}$ CAS Key Laboratory of Pathogenic Microbiology and Immunology, Institute of Microbiology, Chinese Academy of Sciences, 100101 Beijing, China. Correspondence and requests for materials should be addressed to Y.L. (email: yanliu@njmu.edu.cn) or to L.Z. (email: zhanglq@nic.bmi.ac.cn)
} 